\title{
Needs Assessment Activity Report: Fiscal Year 1995
}
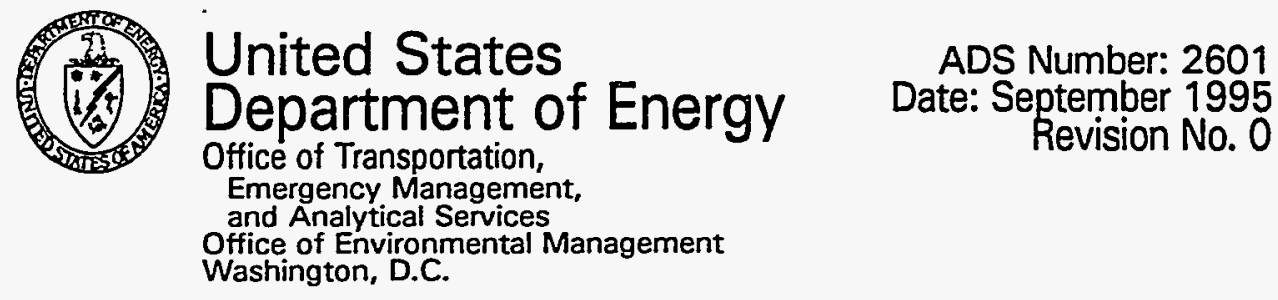

Office of Transportation

Emergency Management,

Office of Environmental Management

Washington, D.C.

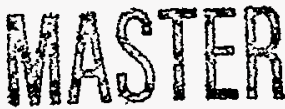

Approved for Public Release

DISTRIBUTION OF THLS DOCUMENT IS UALHITED 
LEGAL DISCLAIMER

This report was prepared as an account of work sponsored by an agency of the United States Government. Neither the United States Government nor any agency thereof, nor any of their employees, nor any of their contractors, subcontractors or their employees, makes any warranty, express or implied, or assumes any legal liability or responsibility for the accuracy, completeness, or any third party's use or the results of such use of any information, apparatus, product, or process disclosed, or represents that its use would not infringe privately owned rights. Reference herein to any specific commercial product, process, or service by trade name, trademark, manufacturer, or otherwise, does not necessarily constitute or imply its endorsement, recommendation, or favoring by the United States Government or any agency there of or its contractors or subcontractors. The views and opinions of authors expressed herein do not necessarily state or reflect those of the United States Government or any agency thereof.

This report has been reproduced from the best available copy. Available in paper copy and microfiche.

Available to the U.S. Department of Energy

and its contractors from

U.S. Department of Energy

Office of Scientific and Technical Information (OSTI)

P.O. Box 62

Oak Ridge, TN 37831

(615) $576-8401$

Available to the public from the U.S. Department of Commerce National Technical Information Service (NTIS)

5285 Port Royal Road

Springfield, VA 22161

(703) 487-4650

Printed in the United States of America

DISCLM-1.CHP (8-95) 


\section{DISCLAIMER}

Portions of this document may be illegible in electronic image products. Images are produced from the best available original document. 


\section{Needs Assessment Activity Report: Fiscal Year 1995}

Date Published

September 1995

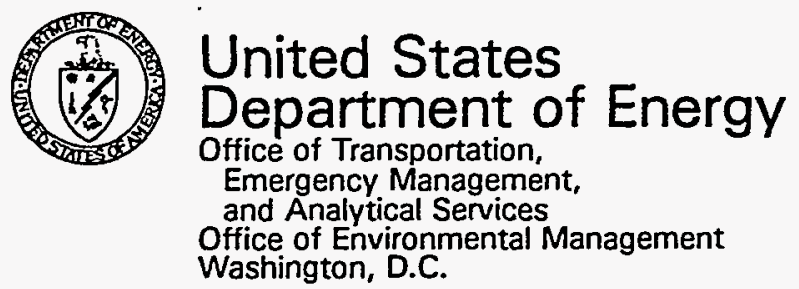

Office of Transportation,

Emergency Management

Office of Environmental Management

Washington, D.C. 


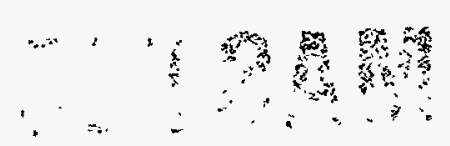




\section{EXECUTIVE SUMMARY}

The Needs Assessment program has assessed the packaging requirements of many U.S. Department of Energy (DOE) sites. These assessments have involved site visits and meetings with personnel involved with transportation and packaging of hazardous materials. By September 1995, 24 DOE facilities had been visited, with 14 site visits occurring in fiscal year 1995. As a result, these sites have been informed of some of the packaging activities that DOE has sponsored and is sponsoring, have been apprised of the affects of upcoming changes to transportation regulations, have discussed their near-term packaging needs, and have shared unique packaging they have developed, which may be of use to other DOE facilities. Program successes include discovery of a need for a reusable Type A liquid sample packaging and its development within another DOE task and establishing communications pathways between DOE sites that have similar transportation and packaging needs.

This report recommends that the Needs Assessment activity continue to pursue the strategy of visiting DOE sites to meet with their transportation and packaging personnel. These visits will ensure that DOE needs are met, communications pathways between DOE sites are established and cultivated, and redundant packaging development is identified. The site visits should be expanded to include meetings with the long-range and strategic planners at each site, and at the DOE-Headquarters level, to ensure that all future transportation and packaging needs are identified early enough to allow adequate transportation assessment and 


\section{DOE/RL-95-94 REV 0}

packaging development. This activity could become a permanent conduit for information and will ensure that all future DOE transportation and packaging needs are satisfied in a cost-effective, timely, and efficient manner. 


\section{CONTENTS}

1.0 INTRODUCTION $\ldots \ldots \ldots \ldots \ldots \ldots \ldots \ldots \ldots \ldots \ldots \ldots \ldots$

2.0 SITE PRESENTATION FORMAT $\ldots \ldots \ldots \ldots \ldots \ldots \ldots \ldots \ldots$

3.0 U.S. DEPARTMENT OF ENERGY SITE VISITS $\ldots \ldots \ldots \ldots \ldots \ldots \ldots \ldots$

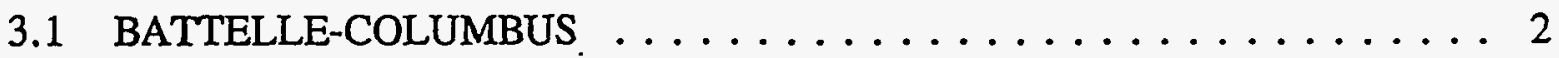

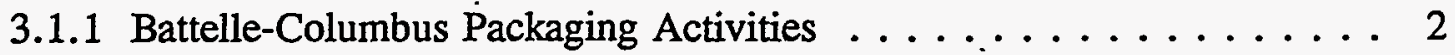

3.1.2 Battelle-Columbus Packaging Needs $\ldots \ldots \ldots \ldots \ldots \ldots \ldots \ldots$

3.1.3 Battelle-Columbus. Packaging Issues $\ldots \ldots \ldots \ldots \ldots \ldots$

3.2 FERNALD ENVIRONMENTAL MANAGEMENT PROJECT . . . . . . 3

3.2.1 Fernald Packaging Activities and Development . . . . . . . . . 3

3.2.2 Fernald Packaging Needs . . . . . . . . . . . . . . 4

3.3 PORTSMOUTH GASEOUS DIFFUSION PLANT . . . . . . . . . . 5

3.3.1 Portsmouth Packaging Activities and Development . . . . . . 5

3.3.2 Portsmouth Packaging Needs $\ldots \ldots \ldots \ldots \ldots \ldots \ldots$

3.3.3 Portsmouth Packaging Issue $\ldots \ldots \ldots \ldots \ldots \ldots \ldots$

3.4 SANDIA NATIONAL LABORATORY $\ldots \ldots \ldots \ldots \ldots \ldots$

3.4.1 Sandia Packaging Development $\ldots \ldots \ldots \ldots \ldots \ldots \ldots$

3.4 .2 Sandia Packaging Needs $\ldots \ldots \ldots \ldots \ldots \ldots \ldots$

3.4.3 Sandia Packaging Issues $\ldots \ldots \ldots \ldots \ldots \ldots \ldots$

3.5 U.S. DEPARTMENT OF ENERGY-ALBUQUERQUE OPERATIONS

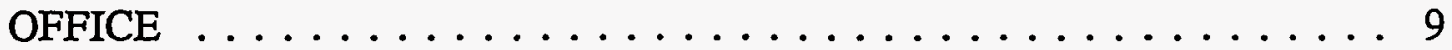

3.5.1 U.S. DEPARTMENT OF ENERGY-Albuquerque Packaging Development . . . . . . . . . . . . 9

3.5.2 U.S. DEPARTMENT OF ENERGY-Albuquerque Packaging Issues $\ldots \ldots \ldots \ldots \ldots \ldots \ldots$

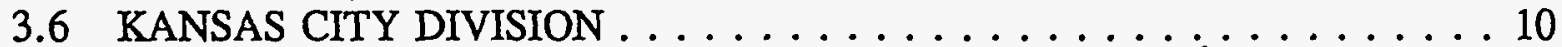

3.6.1 Kansas City Packaging Development . . . . . . . . . . 10

3.6.2 Kansas City Packaging Needs . . . . . . . . . . . . 11

3.6.3 Kansas City Packaging Issue . . . . . . . . . . . . . . 11

4.0 FUTURE NEEDS ASSESSMENT ACTIVITY $\ldots \ldots \ldots \ldots \ldots \ldots \ldots \ldots$

5.0 CONCLUSIONS $\ldots \ldots \ldots \ldots \ldots \ldots \ldots \ldots \ldots \ldots \ldots \ldots \ldots \ldots \ldots \ldots \ldots \ldots$

6.0 RECOMMENDATIONS $\ldots \ldots \ldots \ldots \ldots \ldots \ldots \ldots \ldots \ldots \ldots \ldots \ldots \ldots \ldots$

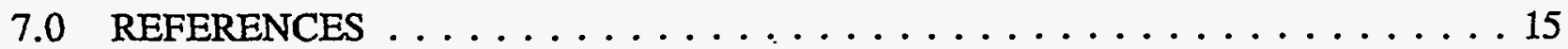




\section{DOE/RL-95-94 REV 0}

\section{LIST OF TERMS}

$\begin{array}{ll}\text { COC } & \text { certificate of compliance } \\ \text { DEB } & \text { 1,4-bis (phenylethynyl) benzene } \\ \text { DOE } & \text { U.S. Department of Energy } \\ \text { KCD } & \text { Kansas City Division } \\ \text { LSA } & \text { low specific activity } \\ \text { NESD } & \text { Nuclear Explosives Safety Division } \\ \text { NRC } & \text { Nuclear Regulatory Commission } \\ \text { PMTS } & \text { Packaging Management Tracking System } \\ \text { POP } & \text { performance oriented packaging } \\ \text { TRU } & \text { transuranic }\end{array}$




\section{FISCAL YEAR 1995 NEEDS ASSESSMENT ACTIVITY REPORT}

\subsection{INTRODUCTION}

Assessment of the packaging needs of the U.S. Department of Energy (DOE) began in fiscal year 1994. This assessment has been completed by the Office of Transportation, Emergency Management, and Analytical Services (EM-26) within the DOE Office of Environmental Management. The Needs Assessment originated because the introductory phase of any packaging development effort with the potential for DOE-wide use involved searching the entire DOE Complex for specific uses for the proposed packaging. During those searches it was found that a wide range of packaging and associated transportation needs had no formal mechanism for being addressed by DOE. Therefore, EM-26 began a task to investigate the different DOE programmatic packaging requirements and needs, evaluate the determined needs as compared to existing packaging resources, and evaluate the needs compared to potential DOE developmental efforts. The first ten Needs Assessment site visits occurred from March to June 1994 and are detailed in DOE/RL-94-106, Revision 1, Needs Assessment Activity Report (DOE/RL 1994). The next ten Needs Assessment site visits occurred from August 1994 to March 1995 and are discussed in DOE/RL-95-43, Revision 0, Needs Assessment Activity Report: April 1995 (DOE/RL 1995). This report will discuss in detail the six site visits that occurred from May to July 1995 and summarize the results of the Needs Assessment to date.

\subsection{SITE PRESENTATION FORMAT}

At the opening of each meeting, the assessment team discusses the role of EM-26 within DOE and its role in packaging development activities. Specific examples of packaging developed, or under development, throughout the DOE Complex - such as the Double Containment-1 packaging, Type A liquid sample packaging, and Type B Drum - are then presented. The presentation has evolved as new packaging that may have use throughout the DOE Complex are discovered or common needs are recognized. Ongoing regulatory activities including performance oriented packaging (POP) and other possible regulatory revisions are discussed. During these meetings, an active discussion between the presenters and the attendees is encouraged and always occurs. After the presentations are complete, the sites are then asked to discuss any packaging needs they may have that are not being satisfied and any packaging they may have developed which could be of use to other DOE facilities. Finally, any unique packaging or shipping facilities are visited.

The attendees at these meetings have, in general, been personnel in the packaging and transportation function within the site organization. Other personnel from site organizations (e.g., waste management or remediation) that make large numbers of shipments or have 
future packaging needs also attend these meetings. Representatives from local DOE offices have sometimes attended the meetings or have been visited separately after the meeting. The format of the meetings has been successful in gathering the most information possible from each DOE site. Site visits typically last for half a day, but some visits have lasted for an entire day.

\subsection{U.S. DEPARTMENT OF ENERGY SITE VISITS}

\subsection{BATTELLE_COLUMBUS}

\subsubsection{Battelle-Columbus Packaging Activities}

Battelle-Columbus consists of two separate facilities that require remediation: the King Avenue Facility in downtown Columbus, Ohio, and the West Jefferson Facility about $27 \mathrm{~km}(17 \mathrm{mi})$ from downtown Columbus. The following remediation activities use radioactive material packagings.

- Battelle-Columbus is currently completing a project to clean up the King Avenue Facility. Shipments consist mainly of mixed hazardous and radioactive low specific activity (LSA) materials shipped in strong, tight packaging to EnviroCare of Utah mixed waste disposal facility. Mixed waste that does not meet

EnviroCare acceptance criteria goes to Hanford, where it will be stored until a burial site can be found or until it can be treated to meet burial site criteria. As of May 1995, approximately 3,540 $\mathrm{m}^{3}(125,000 \mathrm{cu} \mathrm{ft})$ of waste have been shipped for burial or storage. Most of that waste has gone to EnviroCare, but $570 \mathrm{~m}^{3}$ $(20,000 \mathrm{cu} \mathrm{ft})$ have gone to Hanford for long-term storage.

- In 1991 Battelle-Columbus was scheduled to make a transuranic (TRU) waste shipment to Hanford, but political pressure in Washington State prevented the shipment. As a result, Battelle-Columbus has been forced to store their TRU waste onsite indefinitely.

\subsubsection{Battelle-Columbus Packaging Needs}

The packaging needs identified by Battelle-Columbus include the following.

- Cleanup of the West Jefferson facility is scheduled to follow the King Avenue cleanup. However, no funding for cleanup of West Jefferson has been identified in the current DOE-Ohio Field Office plan, so the timetable for the cleanup is uncertain. Cleanup activities will include hot cells containing cabinets, machine, and tools. Materials will be mainly solid TRU, with possibly a small amount of 
liquid. The estimated amount of waste to be disposed may be as much as $935 \mathrm{~m}^{3}$ (33,000 cu ft) of TRU materials. Approximately $75 \%$ will be high level, remote handled TRU. Readings of $500 \mathrm{rem} / \mathrm{hr}$ have been measured on some pieces of material to be disposed. Currently no TRU packaging has been identified. Therefore, Battelle-Columbus is interested in packaging for interim storage.

- There is an interest in finding a way to reduce the cost of the B-25 box $1.2 \mathrm{~m}$ by $1.2 \mathrm{~m}$ by $1.8 \mathrm{~m}$ (nominally $4 \mathrm{ft}$ by $4 \mathrm{ft}$ by $6 \mathrm{ft}$ ), either through centralized DOE procurement of packagings or by purchasing different sizes of packaging. The B-25 packaging is utilized by Battelle-Columbus for shipment and disposal of low-level waste. Costs for the B-25 box previously were $\$ 800.00$ each, but current procurements have reduced that price to $\$ 650.00$ each. Battelle plans to use the B-25 box for low-level waste coming from the West Jefferson project. Battelle is interested is finding a way to purchase B-25 boxes cheaper than the current price. The M-100 Container program sponsored by EM-431 may be able to purchase LSA boxes slightly larger than a B-25 box for a lesser cost. A just-in-time procurement of boxes that is being considered by Westinghouse Hanford Company may also be able to obtain a better price. Battelle-Columbus also mentioned the Sea-Land packaging as a possible alternative to the B-25 box, provided it meets burial site criteria and proves to be more economical.

\subsubsection{Battelle-Columbus Packaging Issues}

The following packaging issues were identified by Battelle-Columbus.

- One of the Battelle-Columbus employees used to work at the Weldon Springs Remediation Project in Missouri and stated that Weldon Springs ships thousands of samples annually for characterization purposes. Weldon Springs may be interested in some of the ongoing Type A liquid and chilled hazardous sample packaging developments.

- Revision 5 to Waste Acceptance Criteria for the Waste Isolation Pilot Plant, WIPP-DOE-069, Revision 4 (WIPP 1991), is underway. Concern was expressed over the effect changes would have on wastes that meet the Revision 4 criteria.

\subsection{FERNALD ENVIRONMENTAL MANAGEMENT PROJECT}

\subsubsection{Fernald Packaging Activities and Development}

Fernald has centralized all of their packaging procurement to help reduce costs and has designated a single point of contact for. purchase of all packaging for the site. Fernald utilizes the Supplier's Quality Inspection Group program to reduce the frequency of inspections of offsite vendors. Most of the packaging nieeds at Fernald are for low-level 
waste containing depleted, natural, or slightly enriched uranium. That waste is disposed of at the Nevada Test Site, will be stored in an onsite storage cell that Fernald is currently designing and building, or, if the waste also contains hazardous constituents, it is disposed at the EnviroCare of Utah mixed waste disposal site. Fernald has been working on the following packaging developments.

- Baling low-level trash and placing 20 bales in a Sea-Land container for shipment to the Nevada Test Site for disposal is under consideration. This trash is shipped as LSA. Fernald determined that baling the waste was more efficient than their previous practice of placing the waste in polyethylene bags and securing it with metal straps.

- Bids are currently being received for a modified metal box for thorium. This metal box will be able to ship six drums loaded with low-level thorium waste. The box can be remotely closed and will be side loading. The box will meet strong, tight requirements for shipment of LSA waste.

\subsubsection{Fernald Packaging Needs}

Packaging needs for the Fernald Site include the following.

- Approximately 650 metric tons of uranium material is located at Fernald. This material is enriched up to $1.25 \%$. Some of this uranium material can be recycled or may be able to be sold to commercial or foreign industry for their use. A large portion of this material is in the form of uranium metal stored in wooden boxes, which have lost certification as Type A packages for fissile material packages (10 CFR 71.55). Fernald would prefer to be able to ship the uranium without having to repackage that material, so alternatives are recertification of the existing packages or developing an overpack for the existing packages.

- A vitrification plant to vitrify most of the waste currently stored in silos is planned. The current plan is to ship that vitrified waste as LSA to the Nevada Test Site for disposal. The vitrified waste is projected to have contact radiation levels of $500-600 \mathrm{mrem} / \mathrm{hr}$, so the packaging selected will need to provide some shielding. Fernald has not yet identified a packaging, but they are studying the Endurorock packaging developed by Scientific Ecology Group. If the Endurorock packaging is used, Fernald projects that 2,500 boxes would be needed to dispose of their silo waste. Fernald intends to place $5,450 \mathrm{~kg}(12,000 \mathrm{lb})$ of material in a $2.4 \mathrm{~m}^{3}$ (84 cu ft) concrete box ( $2.87 \mathrm{~g} / \mathrm{cc}$ with $20 \%$ void volume) and ship 2 boxes at a time on a flatbed truck to the Nevada Test Site. Information and contacts on the Idaho National Engineering Laboratory concrete box were provided to Fernald, because that concrete box may be a less costly alternative to the Endurorock. 


\subsection{PORTSMOUTH GASEOUS DIFFUSION PLANT}

\subsubsection{Portsmouth Packaging Activities and Development}

The Portsmouth Gaseous Diffusion Plant has been run by the United States Enrichment Corporation since 1993, so all ongoing plant operations are the responsibility of the Nuclear Regulatory Commission (NRC). However, DOE is still responsible for cleanup of all waste generated prior to 1993, when they ran the facility. The site contractor at the time of the visit was Martin Marietta, which has since become Lockheed Martin. The site is split up into two separate organizations, one responsible for ongoing operations (Lockheed Martin Utility Services) and one responsible for cleanup of DOE-era waste (Lockheed Martin Energy Systems). The following DOE-related packaging activities and developments are underway at Portsmouth.

- Sampling of highly enriched uranium in early June 1995 to determine if the uranium is a hazardous waste, as defined by the Resource Conservation and Recovery Act of 1976 (RCRA). The analysis results will determine the final disposition of the waste. The uranium is from processing buildings and consists of material left over from many years of operations.

- As needed, Portsmouth borrows a 15,000-kL (4,000-gal) tanker from the Oak Ridge K-25 Plant to make shipments of nonradioactive polychlorinated biphenyls to the incinerator facility at $\mathrm{K}-25$.

- Portsmouth currently ships 416-L (110-gal) drums of radioactive waste to the Hanford Site for disposal. Most of this waste is sludge that has been chromate treated to remove Resource Conservation and Recovery Act materials so it can be disposed of as low-level radioactive waste. B-25 boxes of low-level mixed radioactive and hazardous waste that cannot be treated are shipped to EnviroCare of Utah for disposal.

- Glass jars packaged in coolers to send nonradioactive hazardous liquid samples to laboratories for analysis are currently used. Portsmouth was provided information about several commercially available products that could be used to ship those samples in accordance with new POP requirements.

- A Type A chilled liquid packaging utilizing a 55-gal drum with a cooler and vinyl spacers is being designed. The assessment team provided information to Portsmouth on a commercially-available chilled Type A packaging that may satisfy their need without requiring a new packaging development. 


\subsubsection{Portsmouth Packaging Needs}

Portsmouth identified the following packaging needs.

- Several waste sources are expected to be disposed. A multipurpose source container that could be used for transportation, storage, and disposal would be used by Portsmouth.

- There are several thousand B-25 boxes full of low-level radioactive waste that have rusted and corroded and no longer qualify as strong, tight packagings. Portsmouth prefers to obtain a packaging that could overpack the existing containers without requiring repackaging of the waste material. The overpacks would only need to qualify as strong, tight packagings.

\subsubsection{Portsmouth Packaging Issue}

Portsmouth stated that it is facing cleanup and remediation activities earlier than the three Oak Ridge National Laboratory Sites and the Paducah Gaseous Diffusion Plant (other Lockheed Martin Energy Systems Sites) because the State of Ohio will not permit any additional storage areas onsite and the existing storage areas are nearing capacity. Therefore, Portsmouth expects to be the first Lockheed Martin Site to run into many cleanup-related items such as characterizing waste at offsite laboratories and finding acceptable packaging for their waste. Portsmouth anticipates near-term needs for sample packaging and multipurpose packaging that can be used for transportation, storage, and disposal.

\subsection{SANDIA NATIONAL LABORATORY}

\subsubsection{Sandia Packaging Development}

Sandia identified that they are currently developing the following packagings.

- Sandia and General Atomics have been developing a Defense High-Level Waste cask for the DOE Office of Civilian Radioactive Waste Management, which may be used to ship vitrified defense waste to a final disposal site or to an interim storage location. 'The Defense High-Level Waste cask will be Type B packaging that weighs approximately $20,412 \mathrm{~kg}(45,000 \mathrm{lbs})$ and has an internal cavity with a diameter of $64 \mathrm{~cm}(25 \mathrm{in}$.) and a length of about $305 \mathrm{~cm}$ (120 in.). The Defense High-Level Waste cask will provide only single containment for the vitrified waste, because the vitrified form of the waste is also a barrier to accidental dispersal of radionuclides. The DOE Office of Civilian Radioactive Waste Management is trying to obtain a NRC exemption from the 10 CFR 71.63 requirement for double containment of more than $20 \mathrm{Ci}$ of plutonium. NRC 
currently exempts reactor fuel elements and metal or metal alloy from the double containment requirement and has provisions to exempt other plutonium bearing solids on a case-by-case basis. The DOE Office of Civilian Radioactive Waste Management believes that the vitrified defense waste will also receive that exemption.

- Six POPs have been developed that are used to ship nonradioactive hazardous materials. The containers meet Variation 2 (49 CFR 178.601 [g] [2]) requirements for combination packaging and are constructed out of plywood, pine, or fiberboard, and come in $30 \mathrm{~cm}$ (12 in.) and $46 \mathrm{~cm}$ (18 in.) cubes.

- Sandia is developing or has recently developed the following packagings for DOE's Office of Defense Programs:

- H1616 packagings for tritium reservoirs. Two versions of this packaging are available. Both versions fit inside of a $61 \mathrm{~L}$ (16-gal), stainless-steel drum. One version is constructed with thinner walls and is used for reservoirs confirmed to be intact, while the second version has thicker walls and utilizes 1,4-bis (phenylethynyl) benzene (DEB) hydrogen getter as a filter within the packaging to ensure there is no tritium leakage.

- AT-401R and AT-402R packagings. These packagings were designed specifically for use by the Russians and will be used for shipment and storage of their weapons components. The Defense Nuclear Agency is purchasing 20,000 of these containers to provide to the Russians.

- AT-400A, which is under joint development by Sandia, Los Alamos, and Pantex. The AT-400A will primarily be used for long-term storage of plutonium, but will also meet transportation requirements. The AT-400A will also be a Type B packaging certified by DOE-Albuquerque that can be used to transport the plutonium within a Safe, Secure Transport. AT-400A containers will first be used for storage in December 1995 and will be certified for transport soon thereafter.

- Sandia developed the H1636A packaging for shipment of nuclear weapons materials after the unlikely event of an accident. The H1636A has an outer diameter of $127 \mathrm{~cm}$ (50 in.) and a length of $287 \mathrm{~cm}(113 \mathrm{in}$.). The H1636A was designed to meet Type $B$ requirements, with the goal of meeting proposed International Atomic Energy Agency Type C packaging requirements for air transport of large quantities of radioactive material. This packaging has also undergone testing and meets all requirements for Type B packaging. However, NRC or DOE Office of Facility Safety Analysis (EH-32) certification for the packaging has not yet been obtained, and must be obtained before the H1636A can be used for nonweapons materials. 


\subsubsection{Sandia Packaging Needs}

Sandia identified the following packaging needs.

- A wide variety of rocket motors will need to be shipped to disposal sites for destruction. These rocket motors are typically $0.6 \mathrm{~m}^{2}\left(2 \mathrm{ft}^{2}\right)$ and 2- to 3-m (6- to 8 - $\mathrm{ft}$ ) long, but some of the motors are up to $8 \mathrm{~m}(25 \mathrm{ft})$ long. Rocket motors packaged before October 1, 1991, do not have to be shipped in accordance with POP requirements, as long as they are shipped before October 1, 2001. However, if the rocket motor has been opened, repackaged, or packaged after October 1991, then shipment in POP will be required as of October 1996. The current packaging for the rocket motors does not meet POP requirements and will not fit inside of the Multipurpose Explosives packagings under development because of the length of the rocket motors, so a new packaging will have to be developed.

- A program is under development at Sandia to produce radioisotopes for medical uses, with the main focus on $\mathrm{Mo}^{99}$ (which decays to $\mathrm{Tc}^{99}$, the isotope used in the medical program). Sandia stated that an Environmental Impact Statement is being prepared for the Medical Radioisotope Program that will determine its future packaging needs. Based on current program projections, Sandia considers that two packagings will be needed to support this program: a product packaging and a waste packaging. At present the product is shipped in the FL-10 packaging. However, Sandia is interested in a new packaging because the FL-10 can no longer be fabricated because it is a Type B( )F packaging. The FL-10 Certificate of Compliance (COC) expires in June 1999. The waste from the irradiation of the target material is currently shipped in a B-3 container, which also is a Type B( )F packaging whose COC expires in December 1995. A request for a five year extension of the B-3 COC has been submitted to the NRC and is expected to be approved. However, both of these are grandfathered packagings that can no longer be manufactured, so as the existing packages age, replacements cannot be obtained. The NRC has also indicated that the next revision to their regulations (which is expected to occur before the renewed COCs expire and will implement 1985 International Atomic Energy Agency regulations for transport of radioactive materials) will phase out the grandfathered packages so they can be replaced by packages manufactured to the new regulations. Replacements to both the FL-10 and B-3 packagings will be needed before their current COCs expire.

\subsubsection{Sandia Packaging Issues}

Sandia identified several packaging issues during discussions.

- Inquiries were made as to whether efforts were underway to develop packagings that would satisfy common DOE needs. Sandia was informed of the role of EM-26 in packaging development and its sponsorship of the DOE Packaging 
Council, which has been established to improve communication among DOE contractors and to recommend solutions to common needs. Sandia was also informed of several EM-26 sponsored on-going packaging developments such as Type B Drum, Laboratory Sample Packaging, and Multipurpose Explosives packagings that are underway and will satisfy common needs.

- The Packaging Management Tracking System (PMTS) concept of having a database of all available hazardous and radioactive materials packagings within the DOE, as well as the custodian and the location of those packagings, interested Sandia. One of the advantages of PMTS mentioned by Sandia will be the ability to track who is in possession of Sandia-owned packagings, so Sandia can contact those facilities to arrange return of the packaging. Sandia stated that they often have difficulty getting other DOE facilities to return empty packagings that Sandia has shipped to them, which increases Sandia's packaging costs.

\subsection{U.S. DEPARTMENT OF ENERGY-ALBUQUERQUE OPERATIONS OFFICE}

\subsubsection{U.S. Department of Energy-Albuquerque Packaging Development}

The Nuclear Explosives Safety Division (NESD) is responsible for designing, developing, and procuring packaging for DOE nuclear explosives, as well as ensuring the safety of DOE nuclear explosives during shipment. NESD focuses solely on packagings that utilize the National Security Exemption (49 CFR 173.7[b]) and are escorted during shipment. NESD utilizes several DOE facilities to assist with their mission, including the Y-12 facility at Oak Ridge National Laboratory and Sandia. NESD stated that the Horizontal Shipping Container was developed by Y-12 for shipment of specific weapons components, and could possibly be used to overpack two 55-gal drums for shipment. The Horizontal Shipping Container meets all Type B packaging requirements, will be certified by DOE-Albuquerque, has inner dimensions of $65 \mathrm{~cm}(25.5 \mathrm{in}$.) diameter by $207 \mathrm{~cm}(81.3 \mathrm{in}$.) long, and has a maximum gross weight of $20,412 \mathrm{~kg}(4,500 \mathrm{lb})$. There will be three versions of the Horizontal Shipping Container for three different weapons components. Each version of the Horizontal Shipping Container will have slightly different cavity dimensions.

\subsubsection{U.S. Department of Energy-Albuquerque Packaging Issues}

NESD stated that their programs have no need for new packaging development, because all of their future packaging needs can either be met by existing packagings or by modifying or performing risk analyses on existing packagings. However, NESD raised the following packaging issues.

- Development of an unclassified weapons packaging database, similar to PMTS has been sponsored. NESD stated that they were interested in combining efforts with PMTS developers so one database would cover all DOE packagings. 
This information was provided to PMTS developers so they can contact NESD and explore the possibility of combining the two databases.

- Various sizes of drums, known as drum type containers, with Celotex inner linings around an inner containment to ship materials with low dose rates have been developed. The drum type containers are all Type $B$ packages that have been certified by DOE-Albuquerque for use. Several thousand of these containers have been excessed and are stored at the Y-12 facility. NESD and Y-12 are both interested in finding other users for these packagings, most of which are in usable condition. Y-12 stated that they are willing to share information about the various sizes of available drum type containers with any potential DOE users.

- NESD has also excessed a large amount of handling gear (H-gear) that was used for loading and unloading weapons. NESD considers that some of the H-gear could be used as an overpack for LSA or Type A materials. NESD stated that they are willing to share information about the various sizes of available $\mathrm{H}$-gear with any potential DOE users.

\subsection{KANSAS CITY DIVISION}

\subsubsection{Kansas City Packaging Development}

Kansas City Division (KCD) has developed the following packaging-related items.

- KCD fabricates most of their own POP that they use. They have purchased their own fiberboard box machine to fabricate those boxes and also fabricate wooden boxes and metal cans. KCD competitively bid the contract for POP testing of their packaging designs, which was awarded to a testing laboratory near St. Louis.

- Three different types of hydrogen getters, which are mainly used to control tritium leakage in weapons and military packaging, have been produced. As part of a different project, KCD tested the most recently developed hydrogen getter material, DEB, in a gas atmosphere that closely simulated that of a Hanford Site waste tank. The testing included exposing DEB to a known inhibitor: carbon monoxide. The testing found that under all conditions the DEB functioned, although at slower rates in the presence of carbon monoxide or when wetted. The test results show that DEB could be used as a reliable method of hydrogen or tritium control in radioactive materials packaging. 


\subsubsection{Kansas City Packaging Needs}

KCD identified the following packaging needs.

- They have been unable to obtain packaging for 4 to $19 \mathrm{~L}$ ( 1 to $5 \mathrm{gal}$ ) of - poisonous liquids that require separation from foodstuffs. $\mathrm{KCD}$ has been able to ship 4-L (1-gal) containers by placing the liquid in a container inside of a nylon sealed bag, which provides a pressure boundary. KCD would prefer to ship larger volumes per package if possible.

- KCD has some large nuclear explosive look-alike packages that contain explosives, but no radioactive material, and will eventually require shipment offsite. These packages are about $2 \mathrm{~m}(8 \mathrm{ft})$ long, so there are no readily available POP overpacks that could ship these nuclear explosive look-alike. KCD does not have very many of these expensive nuclear explosive look-alike, so they could not provide eight items required by their POP test facility for POP testing. In addition, the shape of the nuclear explosive look-alike is classified, so $\mathrm{KCD}$ could not provide them to the test facility, even if they had enough available.

- Shipments of corrosive liquids to other facilities in packaging containing dry ice to keep the samples frozen. These samples are shipped in specification packagings that will become obsolete in October 1996. KCD needs to obtain a POP that uses dry ice for cooling to ship these samples. KCD is aware of several POP that use liquid ice for cooling liquid hazardous materials, but are not familiar with any POP that use dry ice for cooling.

\subsubsection{Kansas City Packaging Issue}

KCD stated that they are concerned the focus of DOE packaging activity is on radioactive materials, with little attention paid to nonradioactive hazardous materials. KCD makes very few radioactive materials shipments, but a large number of hazardous materials shipments. Other than the Multipurpose Explosives packaging, KCD is unaware of any DOE-sponsored packaging development for nonradioactive hazardous materials.

\subsection{FUTURE NEEDS ASSESSMENT ACTIVITY}

Among the larger facilities that still need to be visited are Nevada Test Site, Paducah, and the Y-12 Plant at Oak Ridge. Several other smaller research and development facilities may also be visited because smaller facilities are unlikely to have resources available to develop their own packaging. More detailed visits to larger sites that have already been visited may be required to ensure that long-term packaging needs or any recently developing needs are addressed. The initial site visits have included personnel aware of existing or 
near-term packaging needs, but have not included personnel cognizant of long-term

packaging needs. Including DOE-Headquarters and strategic planners at each site, as well as representatives from site organizations that may have long-term packaging needs that have yet to be considered (e.g., a facility which has a large inventory od waste, has never made shipments before, and is scheduled to be decommissioned within several years), will ensure that all required packagings are available when they are needed.

\subsection{CONCLUSIONS}

The site visit format has been very effective to date. The sites visited have been cooperative and forthcoming with their packaging developments, needs, and issues. Visiting each site, in lieu of having one large meeting with attendees from all DOE sites, allows participation by site organizations not fully devoted to transportation and packaging, such as Waste Management and Analytical Laboratories. This increases the input from each site and, in some cases, has led to increased communications between various site personnel.

The Needs Assessment has ascertained that all DOE facilities visited to date have packaging needs that cannot be satisfied by existing packagings. Most facilities state that integration of packaging throughout the DOE Complex and greater coordination between DOE facilities would improve efficiency, timeliness, and cost-effectiveness. The following have been identified by the Needs Assessment to date as the most prevalent packaging needs and issues throughout the DOE Complex.

- Replacements for grandfathered Type B packagings. Many DOE facilities are using NRC- or DOE-certified Type B packagings that do not meet current Type B packaging standards, but are acceptable for use today because of a grandfather clause placed into the Type $B$ packaging regulations when the regulations were last revised. Examples of these packagings are the B-3 and BMI-1 casks, and the FL-10, Super Tiger, and LP-50 containers. When the NRC regulations are revised to incorporate 1985 revisions to International Atomic Energy Agency Safety Series \#6, the certifications for those grandfathered packagings will not be renewed. Therefore, new packaging development programs are necessary to ensure that replacement packagings are available when the existing packagings become obsolete.

- Packaging for plutonium in various forms. The Savannah River Site is developing new packagings for plutonium metal and plutonium oxide, which are known as the 9972-9975 containers. However, packagings are needed for plutonium-contaminated waste, residue material at Rocky Flats, and, if the decision is made to dispose of excess weapons-grade plutonium, vitrified plutonium. The TRUPACT II container will be able to ship some of the waste material, but as a result of restrictions in the amount of fissile material and gas generation allowed within the TRUPACT II, some waste and all residue and 
vitrified plutonium will need alternative packaging. No other existing packaging can reasonably ship the rest of this material. The Type B Drum packaging under development throughout the DOE Complex should be able to ship most of the plutonium waste and residue material, as well as vitrified plutonium.

- Overpacks for large volume items - ranging from strong, tight containers to Type B packagings. Many facilities have stored waste in containers that have worn to the point of becoming unusable, but now must ship that waste to disposal sites. Most of these containers are either 55 -gal drums or $1.2 \mathrm{~m}$ by $1.2 \mathrm{~m}$ by

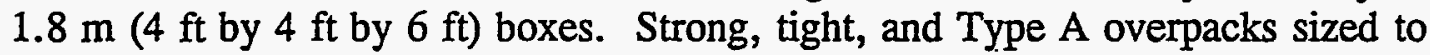
fit these existing containers would prevent facilities from repackaging all of this waste. Several other facilities have boxes containing Type B quantities of waste (mainly TRU) that are at least $1.2 \mathrm{~m}$ by $1.2 \mathrm{~m}$ by $2.4 \mathrm{~m} \mathrm{(} 4 \mathrm{ft}$ by $4 \mathrm{ft}$ by $8 \mathrm{ft}$ ). A Type B overpack would allow these large items to be shipped to either a central location for repackaging into containers that fit inside of the TRUPACT II container (which would reduce the number of sites required to repackage the waste) or actually shipped to Waste Isolation Pilot Plant if its waste acceptance criteria is changed to permit use of packagings other than the TRUPACT II or the NuPac 72-B.

- Heavily shielded Type B packaging. This packaging would be for accelerator targets generated for research and development experiments and for older sources that are stored at facilities throughout the DOE Complex that no longer have certified packaging. Any packaging developed for these needs would have to be able to ship a wide variety of contents, because many of the accelerator targets generated and older sources are one-of-a-kind in nature (unusual radionuclide composition).

- Radioactive liquid packaging with capacities of $4 \mathrm{~L}(1 \mathrm{gal})$ or greater. At present, there is no available packaging certified for offsite use that can ship more than $1 \mathrm{~L}$ (.3 gal) of radioactive liquid. The PAS-1 cask is undergoing the certification process to be able to ship up to $4 \mathrm{~L}$ ( $1 \mathrm{gal}$ ) of Type B liquid, and 3 DOE sites are in the process of purchasing the LR-56 packaging that can ship up to 4,000 L (1,057 gal) of Type A radioactive liquid offsite and Type B liquid onsite. The PAS-1 is expected to be certified in 1995 and the first LR-56 should be delivered by December 1995. However, there is no other packaging development effort underway that will specifically be able to ship 55-gal drums of radioactive liquid, which is a widespread DOE need.

- Standardized waste packaging that meets all requirements for transportation, storage, and disposal. Several sizes of standardized packaging are needed: $0.6 \mathrm{~m}$ by $0.6 \mathrm{~m}$ by $1.8 \mathrm{~m}(2 \mathrm{ft}$ by $2 \mathrm{ft}$ by $6 \mathrm{ft}), 0.9 \mathrm{~m}$ by $0.9 \mathrm{~m}$ by $1.8 \mathrm{~m}$ ( $3 \mathrm{ft}$ by $3 \mathrm{ft}$ by $6 \mathrm{ft}$ ), $1.2 \mathrm{~m}$ by $1.2 \mathrm{~m}$ by $2.1 \mathrm{~m}$ ( $4 \mathrm{ft}$ by $4 \mathrm{ft}$ by $7 \mathrm{ft}$ ), a box to overpack $1.2 \mathrm{~m}$ by $1.2 \mathrm{~m}$ by $2.4 \mathrm{~m}$ ( $4 \mathrm{ft}$ by $4 \mathrm{ft}$ by $8 \mathrm{ft}$ ) boxes, a Conex-type box, and a 55-gal drum. Both strong, tight and Type A versions of these packagings would be used. The specifications for these containers should be 
written so the slightly activated metals, which exist in large quantities throughout the DOE Complex, can be used to manufacture these waste packagings, if desired. Standardizing waste packaging will simplify disposal site operations, reduce costs by eliminating the need for each site to develop its own packaging specifications, and will make it easier for sites to combine procurements to reduce overall costs.

- POP for explosives. The Multipurpose Explosive packagings under development at this time should satisfy this need for most existing explosives packages. However, several sites have rocket motors and other explosives packages that are too large to fit inside the two versions of the Multipurpose Explosive packagings under development at this time. A third version of Multipurpose Explosive packaging that has dimensions of at least $0.6 \mathrm{~m}$ by $0.6 \mathrm{~m}$ by $2.4 \mathrm{~m}(2 \mathrm{ft}$ by $2 \mathrm{ft}$ by $8 \mathrm{ft}$ ) will be able to ship most remaining explosives.

Most of these packaging needs are needed to support environmental cleanup activities throughout the DOE Complex. These activities fall within the scope of DOE Office of Environmental Management programs. The heavily-shielded packaging for accelerator targets and some of the replacements for grandfathered Type B packagings are needed to support the ongoing DOE Office of Energy Research program, while the POP for explosives is required to support the DOE Office of Defense Programs and the vitrified plutonium packaging will support the DOE Office of Fissile Material Disposition.

The Needs Assessment activity has found several packaging developments, including the Idaho National Engineering Company Concrete Box, Multipurpose Explosive packagings, Type B Drum, Savannah River $9972-9975$ plutonium packagings, and packagings developed by DOE's Office of Defense Programs that could be used throughout the DOE Complex to satisfy many of the needs described in this report. It has also initiated other important developments including the Hedgehog and 1-L Liquid Shipper Type A liquid sample packagings that have been developed by EM-26. The Needs Assessment has the potential to lead to many more packaging development efforts by several different facilities throughout the DOE Complex. Finally, the Needs Assessment activity has opened up communication pathways between various DOE sites that should help sites pool their resources and improve efficiency. This rewarding activity should help the DOE Complex, as a whole, become more efficient in transportation and packaging.

\subsection{RECOMMENDATIONS}

Continued visits to sites developing packaging will allow DOE to determine which sites have packagings that could be of use to other sites. DOE can also coordinate that development and ensure that the needs of as many sites as possible are addressed. These functions will make all DOE transportation and packaging activities more efficient and productive. 
The Needs Assessment activity should also be expanded to involve the long-range

planners at each site and at DOE-Headquarters. Presently, the visits have, in general, only included personnel aware of the immediate and near-term packaging needs at each site. Therefore, only the current and near-term packaging needs of each site have been included. Expanding the scope of the visits to include long-range planners at each site, and at the DOE-Headquarters level, would enable DOE to determine future packaging needs. It would also prioritize development of those packagings, along with any technology required to support development, and ensure that the required packagings are available when needed.

\subsection{REFERENCES}

10 CFR 71, "Packaging and Transportation of Radioactive Materials," Title 10, Code of Federal Regulations, Part 71, as amended, U.S. Nuclear Regulatory Commission, Washington, D.C.

49 CFR 173, "Shippers-General Requirements for Shipments and Packaging," Title 10, Code of Federal Regulations, Part 173, as amended, U.S. Department of Transportation, Washington, D.C.

DOE/RL, 1994, Needs Assessment Activity Report, DOE/RL-94-106, Revision 1, U.S. Department of Energy, Richland, Washington.

DOE/RL, 1995, Needs Assessment Activity Report: April 1995, DOE/RL-95-43, Revision 0, U.S. Department of Energy, Richland, Washington.

Resource Conservation and Recovery Act of 1976, 42 USC 6901 et seq.

WIPP, 1991, Waste Acceptance Criteria for the Waste Isolation Pilot Plant, WIPP-DOE-069, Rev. 4, Waste Isolation Pilot Plant, Carlsbad, New Mexico. 